\title{
Associations between Zinc Deficiency and Metabolic Abnormalities in Patients with Chronic Liver Disease
}

\author{
Takashi Himoto ${ }^{1, *}$ and Tsutomu Masaki ${ }^{2}$ \\ 1 Department of Medical Technology, Kagawa Prefectural University of Health Sciences, 281-1, Hara, \\ Mure-Cho, Takamatsu, Kagawa 761-0123, Japan \\ 2 Department of Gastroenterology and Neurology, Kagawa University School of Medicine, Kagawa 761-0123, \\ Japan; tmasaki@med.kagawa-u.ac.jp \\ * Correspondence: himoto@chs.pref.kagawa.jp; Tel.: +81-87-870-1240
}

Received: 14 December 2017; Accepted: 5 January 2018; Published: 14 January 2018

\begin{abstract}
Zinc (Zn) is an essential trace element which has favorable antioxidant, anti-inflammatory, and apoptotic effects. The liver mainly plays a crucial role in maintaining systemic $\mathrm{Zn}$ homeostasis. Therefore, the occurrence of chronic liver diseases, such as chronic hepatitis, liver cirrhosis, or fatty liver, results in the impairment of Zn metabolism, and subsequently Zn deficiency. Zn deficiency causes plenty of metabolic abnormalities, including insulin resistance, hepatic steatosis and hepatic encephalopathy. Inversely, metabolic abnormalities like hypoalbuminemia in patients with liver cirrhosis often result in Zn deficiency. Recent studies have revealed the putative mechanisms by which $\mathrm{Zn}$ deficiency evokes a variety of metabolic abnormalities in chronic liver disease. $\mathrm{Zn}$ supplementation has shown beneficial effects on such metabolic abnormalities in experimental models and actual patients with chronic liver disease. This review summarizes the pathogenesis of metabolic abnormalities deriving from $\mathrm{Zn}$ deficiency and the favorable effects of $\mathrm{Zn}$ administration in patients with chronic liver disease. In addition, we also highlight the interactions between $\mathrm{Zn}$ and other trace elements, vitamins, amino acids, or hormones in such patients.
\end{abstract}

Keywords: zinc deficiency; HCV-related chronic liver disease; nonalcoholic steatohepatitis; liver cirrhosis; insulin resistance; hepatic steatosis; hepatic encephalopathy; iron overload; lipid peroxidation; insulin-like growth factor-1

\section{Introduction}

Zinc ( $\mathrm{Zn})$ is an essential trace element that plays pivotal roles in cellular integrity and biological functions related to cell division, growth and development [1,2]. Zn acts as a cofactor for many enzymes and proteins involved in anti-oxidant, anti-inflammatory and apoptotic effects [3]. Zinc-binding proteins represent approximately 10\% of human proteomes, with more than 300 enzymes having zinc ions within their catalytic domains [4]. Two types of $\mathrm{Zn}$ transporters that maintain $\mathrm{Zn}$ homeostasis are identified: ZnTs (zinc transporters) and ZIPs (Zrt-, Irt-like proteins) [5]. ZnTs lower cytoplasmic Zn by transporting $\mathrm{Zn}$ through cell-surface membranes and intracellular organelles, while ZIPs increase cytoplasmic Zn.

$\mathrm{Zn}$ homeostasis is primarily regulated in the liver. Therefore, chronic liver damage results in the impairment of zinc homeostasis, and eventually zinc deficiency [6-11]. Zn deficiency consequently initiates a variety of metabolic abnormalities, including insulin resistance, hepatic steatosis, iron overload and hepatic encephalopathy (HE) in patients with chronic liver disease. By contrast, a decrease in albumin synthesis leads to $\mathrm{Zn}$ deficiency in patients with liver cirrhosis [12]. Recent studies have revealed the putative mechanisms by which $\mathrm{Zn}$ deficiency evokes a variety of metabolic abnormalities in patients with fatty liver, chronic hepatitis, or liver cirrhosis. The interactions between Zn deficiency and these metabolic abnormalities are summarized in Table 1. 
Table 1. Metabolic abnormalities causing zinc deficiency and metabolic abnormalities deriving from zinc deficiency.

\begin{tabular}{cccc}
\hline Disease & Cause of Zinc Deficiency & Outcomes of Zinc Deficiency & References \\
\hline \multirow{2}{*}{ Liver cirrhosis } & $\begin{array}{c}\text { Decrease in albumin synthesis and relative } \\
\text { increase in } \alpha 2 \text {-macroglobulin }\end{array}$ & {$[13,14]$} \\
\cline { 2 - 4 } & Decrease in Zn absorption from the small intestine & & {$[15]$} \\
\hline $\begin{array}{c}\text { Hepatic } \\
\text { encephalopathy }\end{array}$ & Liver cirrhosis & $\begin{array}{c}\text { Decrease in ornithine } \\
\text { transcarbamylase activity }\end{array}$ & {$[16]$} \\
\hline Insulin resistance & Oxidative stress & Iron overload & {$[17]$} \\
\hline Hepatic steatosis & Oxidative stress & $\begin{array}{c}\text { Enhancement of } \\
\text { lipid peroxidation }\end{array}$ & {$[17]$} \\
\hline
\end{tabular}

IGF-1, insulin-like growth factor.

Here, we mainly focus on the metabolic abnormalities deriving from Zn deficiency in patients with chronic liver disease and the beneficial effects resulting from zinc administration in such patients. Finally, the interactions between Zn deficiency and levels of other trace elements, vitamins, amino acids, or hormones are described.

\section{Association between Zn Metabolism and Its Metabolic Abnormality}

\subsection{Zn Deficiency and Liver Cirrhosis}

Liver cirrhosis is considered the most advanced stage of chronic liver disease. An unfavorable hepatic reserve results in numerous metabolic disorders, such as hypoalbuminemia. Consequently, a relative increase in $\alpha 2$ macroglobulin, which more strongly binds to Zn [13], caused a substantial increase in the urinary excretion of Zn [14]. Moreover, Zn absorption from the small intestine was often impaired in patients with liver cirrhosis [15,19]. Such mechanisms result in severe Zn deficiency in patients with liver cirrhosis.

\subsection{Zn Deficiency and Hepatic Encephalopathy}

Hepatic encephalopathy (HE) is one of the most common neuropsychiatric complications in patients with liver cirrhosis. The pathogenesis of HE has not been completely understood, although ammonia is considered to play a key role. Approximately $90 \%$ of patients with liver cirrhosis and HE have elevated ammonia levels in the plasma [9]. HE in liver cirrhosis patients was associated with a high prevalence of $\mathrm{Zn}$ deficiency [20]. Poor $\mathrm{Zn}$ status resulted in the impairment of nitrogen metabolism by reducing the activity of urea cycle enzyme, ornithine transcarbamylase, in the liver $[16,21]$ and of glutamine synthetase in the muscle [22]. Indeed, serum Zn levels were inversely correlated with blood ammonia levels in patients with liver cirrhosis [23].

\subsection{Zn Deficiency and Hepatocellular Carcinoma}

Hepatocellular carcinoma (HCC) is the fifth most common form of cancer worldwide [24]. Liver cirrhosis appears to be a decisive risk factor leading to the progression to HCC.

The roles of trace elements underlying hepatocarcinogenesis have not been fully understood yet, although previous studies have identified a number of signal transduction pathways that are involved in this process. Elevated serum copper $(\mathrm{Cu})$ levels were associated with the development of HCC [25-28]. Hepatic Cu content was significantly higher in the HCC tissue than that in the surrounding liver parenchyma $[29,30]$. By contrast, Zn concentrations in HCC tissues were lower than those in the surrounding hepatic parenchyma [29,30]. Zn may be involved in the regulation of apoptosis in HCC cells [31]. Zn also has a possibility to downregulate hypoxia-inducible factor-1 $\alpha$ (HIF-1 $\alpha$ ) in the malignant cells [32]. Therefore, Zn deficiency may account for the proliferation of HCC 
cells. However, no significant difference in serum Zn levels was apparent between HCC and liver cirrhosis patients [33,34].

Based on the observations of intracellular Zn concentrations in different carcinomas, it has been postulated that these changes in $\mathrm{Zn}$ levels may contribute to the development of tumors by affecting a wide variety of molecular structures, such as receptors, kinases, caspases, phosphatases and transcriptional factors [35].

The decisive role of $Z n$ in malignant transformation may derive from change in the expression of Zn transporters such as Zip4, Zip6, Zip7 and Zip10, as shown by the previous studies on certain types of carcinomas [36-38]. Notably, the expression of Zip14 was decreased during the development of HCC, coupled with a reduction in intracellular Zn levels [39]. Zip14 localizes to the cell membrane of normal hepatocytes and is a functional transmembrane transporter involved in the uptake of zinc into the cell. Therefore, its downregulation may explain the decreased Zn levels in HCC cells. On the other hand, the expression of Zip 4 gene, which is associated with acrodermatitis enteropathica [40], was upregulated in human and mouse HCC tissues, compared with surrounding non-cancerous tissues [41]. Zip4 influenced the expression of matrix metalloproteinase (MMP)-2 and MMP-9, which are directly involved in angiogenesis and the degradation of basement membrane collagen, in the HCC cell lines [42]. MMP-2 and MMP-9 are in the family of zinc-containing enzymes [43]. Therefore, Zip4 may regulate the expression of MMP-2 and MMP-9 by influencing Zn concentration in the HCC tissues.

Serum Zn status may be recognized as a prognostic serological hallmark after initial hepatectomy in HCV-related HCC patients. Imai and colleagues elucidated that HCC patients with lower serum $\mathrm{Zn}$ levels at the preoperative stage had significantly lower overall survival than those with a normal range of $\mathrm{Zn}$ levels [44].

\subsection{Zn Deficiency and HCV Infection}

Hepatitis $\mathrm{C}$ virus $(\mathrm{HCV})$ is known to induce a spectrum of chronic liver diseases from chronic hepatitis to liver cirrhosis, and ultimately to HCC. More than 184 million people worldwide are estimated to be infected with HCV worldwide at present [45]. Persistent HCV infection often evokes mitochondrial oxidative stress [46], and a variety of resulting metabolic abnormalities, including insulin resistance, dyslipidemia, iron overload and hepatic steatosis $[47,48]$. Zn has potential cytoprotective effects against oxidative stress, apoptosis and inflammation [49].

Zn deficiency may trigger oxidative stress in patients with HCV-related chronic hepatitis and liver cirrhosis, termed HCV-related chronic liver disease (CLD) [50]. A decrease in serum Zn levels was observed in patients with asymptomatic HCV-carrier as well as those with HCV-related CLD, compared with serum Zn levels in normal healthy controls [51]. However, no significant correlation was found between serum Zn levels and loads of HCV RNA in patients infected with HCV. These data may imply that HCV infection probably affects Zn metabolism, although HCV itself has no direct effect on serum $\mathrm{Zn}$ levels in those patients.

Previously, NS3 proteinase, which is involved in the process of HCV replication, proved to be a zinc-containing enzyme [52]. In addition, NS5A protein was considered a Zn metalloprotein [53]. These findings suggest that $\mathrm{Zn}$ may have inhibitory effects in the proliferation and replication of $\mathrm{HCV}$.

\subsection{Zn Deficiency in Nonalcoholic Steatohepatitis}

Nonalcoholic fatty liver disease (NAFLD) is currently the most prevalent liver disease worldwide, characterized by the accumulation of triglycerides in the liver, and the absence of excessive alcohol consumption. NAFLD covers a spectrum of liver diseases that range from simple steatosis called nonalcoholic fatty liver (NAFL) through nonalcoholic steatohepatitis (NASH), which is associated with hepatic inflammation and fibrosis in addition to simple steatosis [54].

Previous studies elucidated that dietary habits are likely to affect Zn metabolism in patients with NAFLD. Lower oral intake of Zn was observed in patients with NAFLD than in normal healthy controls [55]. NASH patients had significantly lower oral intake of Zn than NAFL patients [56]. Zn 
deficiency in such patients may be due to this lower $\mathrm{Zn}$ intake. Zn deficiency results in mitochondrial oxidative stress and subsequently iron over load, insulin resistance, and hepatic steatosis in patients with NASH.

$\mathrm{Zn}$ and zinc transporters play crucial roles in the attenuation of endoplasmic reticulum (ER) stress-related signaling and the unfolded protein response (UPR) [57]. Therefore, Zn deficiency may potentially induce or exacerbate ER stress and apoptosis. Kim and colleagues recently elucidated that consumption of a zinc-deficient diet exacerbated ER-stress-induced apoptosis and hepatic steatosis in experimental mice models [58]. The authors proposed that Zip14 mediated Zn transport into hepatocytes to inhibit protein-tyrosine phosphatase $1 \mathrm{~B}$, which suppressed apoptosis and steatosis associated with ER stress [59].

\subsection{Zn Deficiency and Insulin Resistance in Patients with HCV-Related CLD}

Zn plays a pivotal role in the secretion and activation of insulin. Specifically, Zn participates as a potent physiological regulator of insulin signal transduction through its inhibitory effect on protein tyrosine phosphatase $1 \mathrm{~b}$, the key phosphatase that dephosphorylates the insulin receptor [60]. Therefore, it has been well known that $\mathrm{Zn}$ is absolutely indispensable for the regulation of glucose homeostasis. Zn deficiency seems to be associated with the pathogenesis of type 2 diabetes mellitus (DM), supporting the notion that $\mathrm{Zn}$ deficiency may result in the exacerbation of insulin resistance. $\mathrm{Zn}$ deficiency may derive from hyperzincuria in patients with type 2 DM [61].

Insulin resistance and/or concurrent type $2 \mathrm{DM}$ are often associated with the occurrence of HCV-related CLD [62]. Previously, we elucidated that Zn deficiency caused the exacerbation of insulin resistance in patients with HCV-related CLD [17,63]. Zn deficiency may contribute to higher serum ferritin levels and lower IGF-1/IGFBP-3 ratios, surrogate measures for circulating free IGF-1 levels [64], and thus substantially exacerbate the insulin resistance in such patients [18].

Depressed serum Zn levels were found in some patients with NAFLD (unpublished data). Zn deficiency is likely to evoke insulin resistance in such patients by way of almost the same mechanism as chronic HCV infection, including hyperferritinemia and/or lower circulating free IGF-1 levels [65].

Zn deficiency is also observed in patients with primary biliary cholangitis (PBC), an autoimmune liver disease characterized by progressive destruction of the intrahepatic bile ducts, leading to cholestasis [66]. Serum Zn levels are gradually decreased as the hepatic fibrosis develops in those patients. Advanced-stage PBC patients also have higher insulin resistance, suggesting that $\mathrm{Zn}$ deficiency may exacerbate insulin resistance in such patients [67].

\subsection{Zn Deficiency and Iron Overload in Patients with HCV-Related CLD}

Persistent HCV infection and nonalcoholic fatty liver disease (NAFLD) are well recognized cofactors affecting body iron storage [48]. A patient's serum ferritin level is ordinarily used as an indicator of iron storage in the liver. We previously showed an inverse correlation between serum $\mathrm{Zn}$ and ferritin levels in patients with HCV-related CLD, implying that Zn deficiency might result in iron overload in those patients $[17,63]$.

It has been well established that $\mathrm{Zn}$ and iron may compete for access to transporters. Formigari and colleagues suggested that divalent metal transporter 1 (DMT1) is a possible candidate zinc-iron transporter [68]. It is of interest that Zn competed with iron uptake in cells overexpessing Zip14, implicating Zip14 as another possible candidate for transport of both Zn and iron in the liver [69].

\subsection{Iron Overload and Insulin Resistance}

Iron often influences glucose metabolism. The amount of iron storage in the body was found to be significantly associated with the development of glucose intolerance or type 2 DM in a general population [70]. 
In addition, iron overload reciprocally seems to affect insulin action. Iron storage interferes with the production of glucose by the liver. Hepatic extraction of insulin and the body's metabolism of insulin is reduced with increasing iron storage, leading to peripheral hyperinsulinemia.

This status is called "iron overload-related insulin resistance" [71]. Iron overload-related insulin resistance was observed in CLD-C and NAFLD patients with hyperferritinemia, who are frequently associated with hepatic steatosis and/or fibrosis [48,72].

\subsection{Decrease in Circulating Free IGF-1 Levels and Insulin Resistance in Patients with HCV-Related CLD}

Insulin-like growth factor-1 (IGF-1), a liver-derived humoral growth factor, has crucial anabolic and metabolic actions. It is secreted from hepatocytes and has a negative feedback control on growth hormone release from the pituitary gland. The biological activity of IGF-1 is primarily dependent on IGF-binding proteins (IGFBPs). The binding of IGFBP-3 to IGF-1 has been shown to inhibit the bioavailability of IGF-1 [73]. Therefore, free IGF-1 is considered the bioactive form of IGF-1 (Figure 1). However, free IGF-1 levels are difficult to determine directly. The ratio of IGF-1/IGFBP-3 is usually used as a surrogate estimate of free IGF-1 [64].

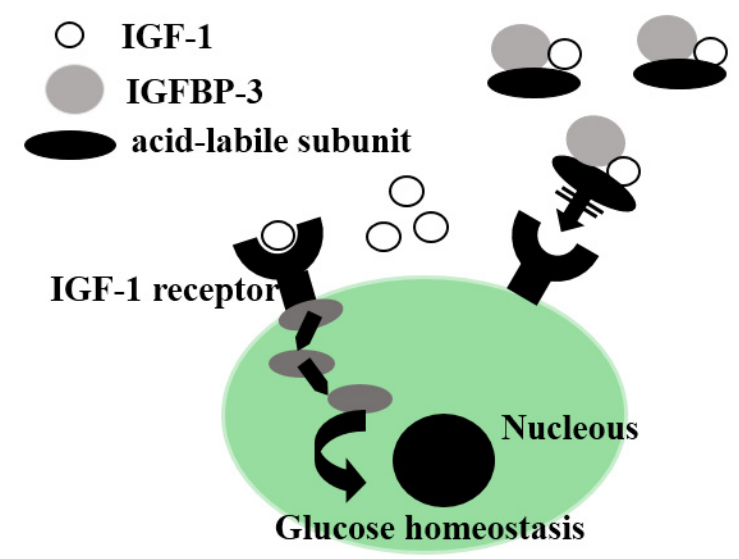

Figure 1. Putative mechanisms by which a decrease in free IGF-1 levels cause insulin resistance in patients with HCV-related CLD. IGF-1, insulin-like growth factor; IGFBP, IGF-binding protein; HCV, Hepatitis $C$ virus; CLD, chronic liver disease.

$\mathrm{Zn}$ is likely to participate in the stabilization of IGF-1 transcripts [74]. Thus, the IGF-1/IGFBP-3 ratio, a surrogate measure for circulating free IGF-1 level, had a positive correlation with serum $\mathrm{Zn}$ levels in patients with HCV-related CLD [18]. It is of interest that the IGF-1/IGFBP-3 ratio was inversely associated with the values of homeostasis model for assessment of insulin resistance (HOMA-IR), an indicator for insulin resistance, suggesting that a lower circulating free IGF-1 concentration might result in the exacerbation of insulin resistance in such patients.

\subsection{Zn Deficiency and Hepatic Steatosis in Patients with HCV-Related CLD}

A previous study demonstrated that $\mathrm{Zn}$ deficiency was linked to hepatic steatosis in an experimental animal model of fatty liver induced by tetracycline [75]. We confirmed that serum $\mathrm{Zn}$ levels were decreased as the degrees of hepatic steatosis developed in patients with HCV-related CLD [17]. Moreover, serum Zn levels were decreased in inverse proportion to the intensity of 4-hydroxy-2'-nonenal (4-HNE), an indicator for lipid peroxidation, in the liver of those patients [17].

$\mathrm{Zn}$ has been considered to participate in the enhancement of peroxisome proliferator-activated receptor- $\alpha$ (PPAR- $\alpha$ ), a regulator of lipid homeostasis [76]. Zn is necessary for the DNA-binding activity of PPAR- $\alpha$. Therefore, Zn deficiency may result in a decline of DNA-binding activity, and thereby facilitate lipid peroxidation, ultimately exacerbating hepatic steatosis. 
We also revealed that a lower IGF-1/IGFBP-3 ratio might cause more advanced hepatic steatosis in patients with HCV-related CLD [18]. A significant correlation was confirmed between insulin resistance and the severity of hepatic steatosis in those patients. Higher insulin resistance may result in a lower ratio of IGF-1/IGFBP-3 in HCV-related CLD patients with severe steatosis (Figure 2). The lower ratio of IGF-1/IGFBP-3 was also observed in patients with NAFLD [77], suggesting that a decrease in circulating free IGF-1 levels may account for exacerbation of insulin resistance and advanced hepatic steatosis.

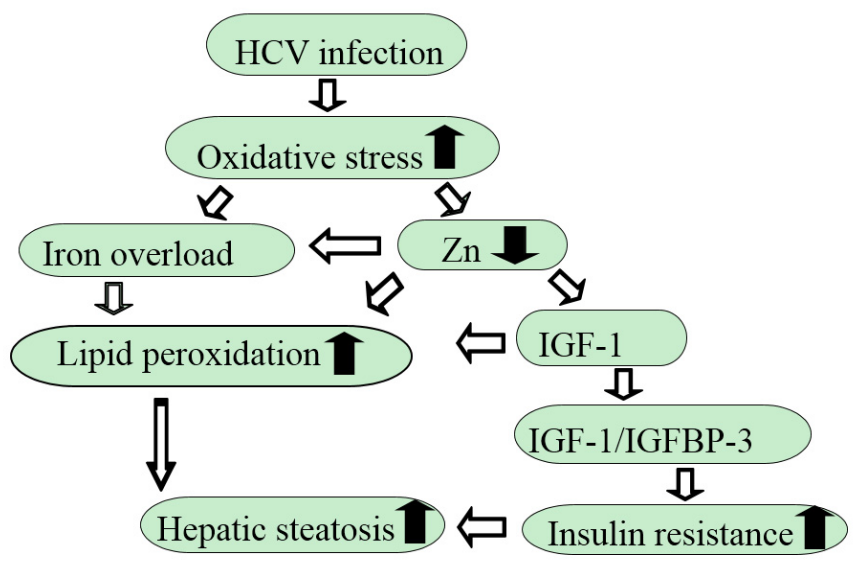

Figure 2. Putative mechanisms by which chronic HCV infection evokes insulin resistance and hepatic steatosis.

Iron overload is also believed to cause lipid peroxidation, and subsequently to lead to hepatic steatosis in patients with HCV-related CLD [72]. We confirmed a significant correlation between the intensity of hepatic 4-HNE expression and serum ferritin levels in such patients [17].

\subsection{Zn Metabolism and Wilson's Disease}

Wilson's disease is an autosomal recessive, hereditary disorder of $\mathrm{Cu}$ metabolism due to defective $\mathrm{Cu}$-transporting ATPase activity, leading to the accumulation of $\mathrm{Cu}$ in the liver and basal ganglia of the brain [78]. The accumulation of $\mathrm{Cu}$ may affect the metabolisms of other trace elements, including $\mathrm{Zn}$ and iron. However, few studies have focused on imbalances of trace elements in patients with Wilson's disease. Ferenci and colleagues previously documented that slightly increased hepatic accumulation of $\mathrm{Zn}$ and iron were observed in such patients [79].

\subsection{Zn Metabolism and Hemochromatosis}

Patients with hereditary hemochromatosis, characterized by HFE point mutations [80], are more susceptible to iron overload when factors such as alcohol, HCV infection, and abnormal porphyrin metabolism are present [48]. Even in the absence of hereditary hemochromatosis, there are several conditions associated with secondary iron overload. A few studies have focused on the relationships between iron overload and other trace element statuses either in experimental models of hemochromatosis or in patients with hemochromatosis. Unfortunately, Zn status in patients with hemochromatosis remains controversial. Vayenas and colleagues elucidated that hepatic $\mathrm{Zn}$ content was increased in iron-overload Wister rats [81]. Adams and colleagues also revealed that hepatic zinc content was significantly higher in the livers of patients with hemochromatosis than that in normal livers [82]. The increase in hepatic Zn content might substantially derive from increased intestinal absorption of $\mathrm{Zn}$ and hepatic sequestration. To the contrary, Beckett and colleagues recently documented that iron overload did not have a significant effect on Zn status [83]. 


\section{Therapeutic Effects of Zn Administration}

Zinc administration has shown favorable effects on metabolic abnormalities in patients with chronic liver disease. The effects of zinc supplementation and possible mechanisms of these effects are summarized in Table 2, and described in detail below.

Table 2. Beneficial effects of zinc administration in patients with chronic liver disease.

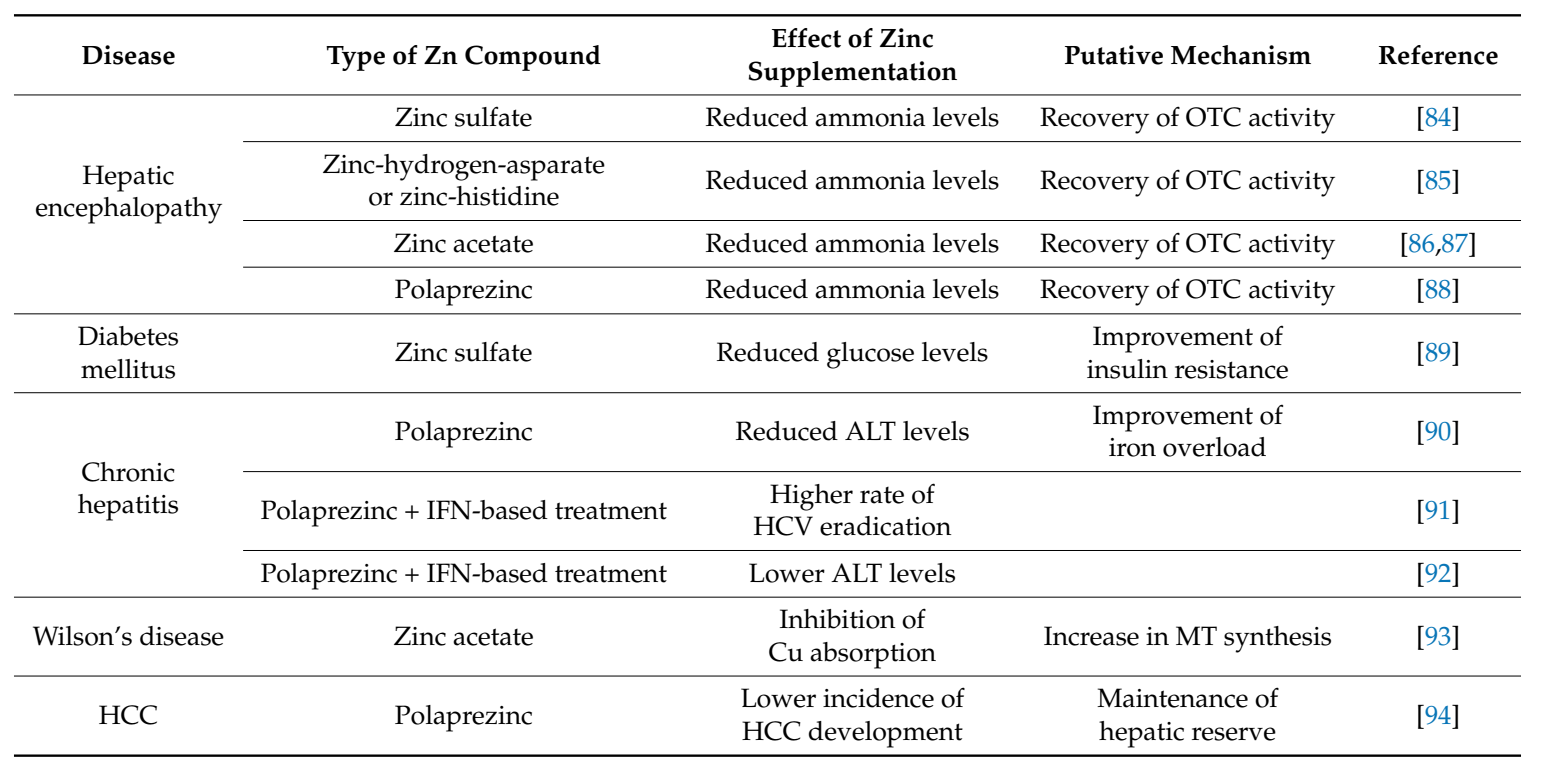

OTC, ornithine transcarbamylase; HCV, hepatitis C virus; IFN, interferon; ALT, alanine aminotransferase; MT, metallothioneine; HCC, hepatocellular carcinoma.

\subsection{Attenuation of Hepatic Inflammation}

Zn has beneficial effects on hepatic inflammation in patients with HCV-related CLD. We previously documented that the administration of polaprezinc, a complex of $\mathrm{Zn}$ and L-carnosine, showed anti-inflammatory effects in the liver by attenuating hepatic iron storage in such patients [90]. However, the administration of zinc did not directly affect HCV viremia in our study, although Takagi and colleagues revealed that the combination therapy of zinc with interferon (IFN)- $\alpha$ was more effective against HCV eradication than IFN treatment alone [91]. Likewise, $\mathrm{Zn}$ administration also prevented an increase in serum alanine aminotransferase (ALT) levels of patients with chronic hepatitis C during IFN-based treatment [92].

\subsection{Improvement of Insulin Resistance}

$\mathrm{Zn}$ supplementation is likely to have favorable effects on impaired glucose tolerance. Yoshikawa and colleagues demonstrated that oral administration of $\mathrm{Zn}$ (II)-dithiocarbamate complex improved hyperglycemia, glucose intolerance and insulin resistance in an experimental animal model of type 2 DM [95]. It is of interest that an increase in adiponectin synthesis by the administration of $\mathrm{Zn}$ complexes resulted in the improvement of insulin resistance in those experimental animal models.

Oral $\mathrm{Zn}$ administrations, using zinc sulfate or zinc acetate, have been prescribed in patients with T2DM. A systemic review by Jayawardena documented that $\mathrm{Zn}$ supplementation had beneficial effects on glycemic control in such patients [96]. The authors speculated that the effect of $\mathrm{Zn}$ might be mediated by increasing IGF-1. Surprisingly, the authors revealed that Zn administration also improved dyslipidemia in T2DM patients. However, all these studies included dietary supplementation with other antioxidant vitamins and minerals together with $\mathrm{Zn}$. Hence, it is difficult to conclude that the beneficial effects were due to $\mathrm{Zn}$ alone. 
It is of interest that long-term $\mathrm{Zn}$ treatment improved impaired glucose tolerance in patients with advanced liver cirrhosis [89]. Further examinations will be required to clarify the efficacy of $\mathrm{Zn}$ administration in HCV-related CLD or NAFLD patients accompanied by insulin resistance.

\subsection{Attenuation of Hepatic Steatosis}

Sugino and colleagues investigated the effect of Zn (polaprezinc) in a mouse model of NASH. Zn supplementation did not affect the steatosis, but visibly attenuated fibrosis in the liver [97]. Another study documented that treatment with zinc sulfate reversed alcohol-induced steatosis in male mice via reactivation of hepatocyte nuclear factor- $4 \alpha$ (HNF- $4 \alpha)$ and PPAR- $\alpha$ [98].

Unfortunately, the effects of $\mathrm{Zn}$ administration on hepatic steatosis in patients with CLD-C or NAFLD has not been fully verified yet. Hence, $\mathrm{Zn}$ supplementation should be evaluated as an optional treatment for such patients [99].

\subsection{Improvement of Hepatic Encephalopathy}

Long-term Zn supplementation significantly improved the grade of HE and blood ammonia levels in patients with liver cirrhosis [84-88]. Zn administration in patients with liver cirrhosis and HE potentially resulted in the recovery of urea synthesis in the liver and glutamine synthesis in the muscle. Supplementation with branched-chain amino acids (BCAAs) enhances detoxification of ammonia from the skeletal muscles by the amidation process for glutamine synthesis [100]. Interestingly, it was found that a combination treatment with BCAAs and Zn decreased blood ammonia levels more than a treatment with BCAAs alone in patients with liver cirrhosis [101].

\subsection{Inhibitory Effect on the Development of HCC}

$\mathrm{Zn}$ administration appears to have a preventive effect on the development of HCC. Matsumura and colleagues documented that chronic hepatitis $C$ patients treated with polaprezinc, a complex of zinc and L-carnosine, had a significantly lower incidence of HCC than those without administration of polaprezinc [94]. Maintenance of favorable hepatic reserve by $\mathrm{Zn}$ supplementation may account for the lower incidence of HCC.

Insulin resistance seems to be one of the risk factors for the development of HCC [102]. Zn supplementation may result in an improvement of insulin resistance in patients with HCV-related CLD or NASH. Accordingly, a treatment with Zn should be considered as a therapeutic strategy in such patients [103].

\subsection{Reduced $\mathrm{Cu}$ Absorption from the Small Intestine}

It has been widely established that oral $\mathrm{Zn}$ administration often provides Wilson's disease patients with favorable effects. Zn administration induced the synthesis of metallothionein (MT), a copper-binding protein [104], in the small intestine and the liver. MT binds to newly absorbed Cu and prevents it from passing from the small intestine into the circulation. Some studies, using experimental animal models for Wilson's disease, have also revealed an increase in hepatic MT synthesis, and sequestration of excess hepatic $\mathrm{Cu}$ content by the administration of $\mathrm{Zn}$ [105]. A significant correlation was found between MT and Zn concentrations in the duodenal mucosa of 15 patients with Wilson's disease by the treatment with zinc sulfate or penicillamine [106]. Accordingly, Zn acetate has been approved for the treatment of Wilson's disease, especially in early stage patients [93].

\section{Interactions between Zinc and Other Trace Elements or Vitamins}

It has been widely recognized that some trace elements, including $\mathrm{Cu}$ and iron, compete with $\mathrm{Zn}$, while selenium and vitamin A are positively associated with Zn status. Table 3 shows interactions between $\mathrm{Zn}$ and other trace elements, vitamins, amino acids, or hormones status. 
Table 3. Interactions between zinc and other trace elements, vitamins, amino acids, or hormones in chronic liver disease.

\begin{tabular}{cccc}
\hline $\begin{array}{c}\text { Other Trace Elements, Vitamins, } \\
\text { Amino Acids, or Hormones }\end{array}$ & Disease or Condition & Correlation & Reference \\
\hline & Liver cirrhosis & Increase in Cu/Zn ratio & {$[33]$} \\
Copper & Liver cirrhosis & Increase in Cu/Zn ratio & {$[34]$} \\
& HCC & Increase in Cu/Zn ratio & {$[33]$} \\
& HCC & Increase in Cu/Zn ratio & {$[34]$} \\
HCC & Increase in Cu/Zn ratio & {$[107]$} \\
Iron & Cugh doficiency & {$[108]$} \\
\hline Selenium & HCV-related CLD & Inverse correlation & {$[17]$} \\
& HCV-related CLD with NAFLD & Inverse correlation & {$[109]$} \\
\hline Vitamin A & Alcoholic liver disease, PBC, liver & Positive correlation & {$[110]$} \\
\hline cirrhosis and autoimmune hepatitis & HCV-related CLD & Positive correlation & {$[111]$} \\
\hline Retinol-Binding Protein & Liver cirrhosis & Positive correlation & {$[112]$} \\
\hline Vitamin D & Liver cirrhosis & Positive correlation & {$[113]$} \\
\hline Branched-chain amino acids & Primary ovarian insufficiency & Positive correlation & {$[114]$} \\
\hline Tyrosine & HCV-related CLD & No significant correlation & {$[51]$} \\
\hline IGF-1 & HCV-related CLD & No significant correlation & {$[51]$} \\
\hline Testosterone & HCV-related CLD & Inverse correlation & {$[18]$} \\
\hline Cu, copper; Zn, zinc; HCC, hepatocellular carcinoma; HCV, hepatitis C virus; CLD, chronic liver disease; NAFLD,
\end{tabular}

\section{1. $\mathrm{Zn}$ and $\mathrm{Cu}$}

It is well known that $\mathrm{Zn}$ competes with $\mathrm{Cu}$ [8]. The risk of $\mathrm{Cu}$ deficiency in patients with continuously high dose of $\mathrm{Zn}$ prescription has been warranted $[108,116]$. High-dose $\mathrm{Zn}$ supplementation causes enterocytes to produce MT which binds to $\mathrm{Zn}$. Whereas, $\mathrm{Cu}$ binds more avidly to MT than Zn, eventually leading to $\mathrm{Cu}$ deficiency [117]. We previously performed the additional treatment with polaprezinc (51mg/day of Zn for 6 months) in 14 patients with HCV-related CLD. However, none of the HCV-related CLD patients on this regimen suffered from $\mathrm{Cu}$ deficiency [90]. To the contrary, a lower intake of $\mathrm{Zn}$ was more effective than a moderately higher intake of $\mathrm{Zn}$ in inducing changes associated with a decreased $\mathrm{Cu}$ status in postmenopausal women [118].

The ratio of serum $\mathrm{Cu}$ to $\mathrm{Zn}$ levels has been utilized as a clinical assessment in certain diseases [119]. Among chronic liver diseases, elevated $\mathrm{Cu} / \mathrm{Zn}$ ratios have been observed in patients with liver cirrhosis or HCC $[33,34]$. Therefore, the ratio of $\mathrm{Cu} / \mathrm{Zn}$ can be monitored for estimating the severity of liver damage. However, the ratio cannot discriminate HCC patients from liver cirrhosis patients. It is of interest that elevation of the $\mathrm{Cu} / \mathrm{Zn}$ ratio was observed in HCC patients alone among hepatobiliary cancer patients [107].

\subsection{Zn and Iron}

Zn also competes with iron. We previously showed a weakly inverse correlation between serum zinc and ferritin levels in patients with HCV-related chronic liver disease [17]. The inverse correlation between serum $\mathrm{Zn}$ and ferritin was also found in HCV-related CLD patients associated with NAFLD [109]. The putative mechanism is explained in the paragraph regarding "zinc deficiency and iron overload" in this review.

Interestingly, Zn supplementation caused an increased iron concentration in the duodenal mucosa of patients with Wilson's disease, although the mechanism of this change remains unclear [106]. Further examinations will be required to clarify this phenomenon in such patients. 


\subsection{Zn and Selenium}

We previously revealed that serum selenium levels were positively associated with serum Zn levels in patients with HCV-related CLD [111]. We also confirmed a positive correlation between serum selenium and albumin levels in such patients. Therefore, selenium deficiency might result in hypoalbuminemia, and subsequently cause Zn deficiency in those patients. Likewise, Thuluvath and Triger found a positive correlation between serum zinc and selenium levels among patients with various chronic liver diseases, including alcoholic liver disease, primary biliary cholangitis, cryptogenic cirrhosis, chronic active autoimmune hepatitis [110].

It is of interest that the administration of selenium modulated serum $\mathrm{Zn}$ levels in diabetic rats fed a zinc-deficient diet [120].

\subsection{Zn and Vitamin A}

A previous study elucidated that significant correlations between serum $\mathrm{Zn}$ and vitamin A or retinol-binding protein (RBP) levels were found in patients with liver cirrhosis [112]. Zn deficiency seems to impair the synthesis of RBP [7,121,122]. Therefore, the authors speculated that Zn deficiency might result in portosystemic shunting, and subsequent vitamin A deficiency by decreasing the release of RBP in such patients [112].

\subsection{Zn and Vitamin D}

Serum 25-hydroxy vitamin D (25-OH vitamin D) levels are also decreased in proportion to the severity of hepatic fibrosis as well as serum $\mathrm{Zn}$ levels in patients with HCV-related CLD [123]. Surprisingly, no significant correlation was found between serum 25-OH vitamin D and $\mathrm{Zn}$ levels in such patients [114], although serum Zn levels were significantly associated with serum 25-OH vitamin D levels among women with primary ovarian insufficiency [113].

\subsection{Zinc and Amino Acids}

Moriyama and colleagues documented that there was not a significant correlation between serum $\mathrm{Zn}$ and BCAA levels in patients with HCV-related CLD, but that an inverse correlation between serum $\mathrm{Zn}$ and tyrosine levels did exist [51]. Therefore, an inverse correlation was found between serum zinc levels and the ratio of BCAA to tyrosine (BTR) in such patients.

Surprisingly, oral administration of BCAA granules caused a decrease in serum Zn levels of patients with liver cirrhosis [124]. The authors speculated that the protein synthesis was facilitated by the administration of BCAAs resulting in consumption of $\mathrm{Zn}$, because $\mathrm{Zn}$ acts at multiple steps in amino acid- and insulin-regulated intracellular signaling pathways, including $\mathrm{mTOR}$. It is of interest that the amount of urinary Zn secretion was related to the infusion of amino acid in patients who received parenteral nutrition [125]. Surprisingly, $\mathrm{Zn}$ bound to amino acids such as aspartate, cysteine and histidine showed the highest absorption concentration, followed by zinc chloride, sulfate and acetate, while zinc oxide showed the lowest bioavailability [116].

\subsection{Zn and Hormones}

It has been well established that $\mathrm{Zn}$ plays a fundamental role in the stability of IGF-1 transcripts [74]. Therefore, Zn deficiency eventually caused a decrease in the synthesis of IGF-1 in patients with HCV-related CLD [18]. Zn supplementation may increase the production of IGF-1 in the livers of patients with liver cirrhosis.

Zn seems to participate in modulating serum testosterone levels in normal men. Therefore, hypogonadism has been linked to Zn deficiency [126]. In contrast, Fuse and colleagues found a significant correlation between serum $\mathrm{Zn}$ and testosterone levels among infertile male patients [115]. Indeed, $\mathrm{Zn}$ supplementation facilitated the synthesis of testosterone in elderly men with marginal $\mathrm{Zn}$ deficiency [9]. 


\section{Conclusions}

This review complied overwhelming evidence that $\mathrm{Zn}$ deficiency is common in patients with chronic liver diseases such as chronic hepatitis and NASH, as well as liver cirrhosis. In such patients, Zn deficiency causes various types of metabolic abnormalities, including insulin resistance, hepatic steatosis, iron overload and hepatic encephalopathy. As expected, these metabolic abnormalities may be recovered by $\mathrm{Zn}$ supplementation. Further trials will be required to verify the beneficial effects of $\mathrm{Zn}$ administration on theses metabolic abnormalities especially in NASH patients.

Author Contributions: T.H. wrote the manuscript. T.M. made critical revision.

Conflicts of Interest: The authors have no conflicts of interest to declare.

\section{References}

1. Wessels, I.; Maywald, M.; Rink, L. Zinc as a gatekeeper of immune function. Nutrients 2017, 9, 1286. [CrossRef] [PubMed]

2. Vallee, B.L.; Falchuk, K.H. The biochemical basis of zinc physiology. Physiol. Rev. 1993, 73, 79-118. [CrossRef] [PubMed]

3. Powell, S.R. The antioxidant properties of zinc. J. Nutr. 2000, 130, S1447-S1454.

4. Leoni, G.; Rosato, A.; Perozzi, G. Zinc proteome interaction network as a model to identify nutrient-affected pathways in human pathologies. Genes. Nutr. 2014, 9, 436. [CrossRef] [PubMed]

5. Liuzzi, J.P.; Cousins, R.J. Mammalian zinc transporters. Annu. Rev. Nutr. 2004, 24, 151-172. [CrossRef] [PubMed]

6. Prasad, A.S. The role of zinc in gastrointestinal and liver disease. Clin. Gastroenterol. 1983, 12, $713-741$. [PubMed]

7. Ritland, S.; Aaseth, J. Trace elements and liver. J. Hepatol. 1987, 5, 118-122. [CrossRef]

8. McClain, C.J.; Marsano, L.; Burk, R.F.; Bacon, B. Trace metals in liver disease. Semin. Liver Dis. 1991, 11, 321-339. [CrossRef] [PubMed]

9. Grüngreiff, K. Zinc in liver disease. J. Trace Elem. Exp. Med. 2002, 15, 67-78. [CrossRef]

10. Mohammad, M.K.; Zhou, Z.; Cave, M.; Barve, A.; McClain, C.J. Nutrition in clinical practice. Nutr. Clin. Pract. 2012, 27, 8-20. [CrossRef] [PubMed]

11. Grüngreiff, K.; Reinhold, D.; Wedemeyer, H. The role of zinc in liver cirrhosis. Ann. Hepatol. 2016, 15, 7-16. [CrossRef] [PubMed]

12. Goode, H.F.; Kelleher, J.; Walker, B.E. Relation between zinc status and hepatic functional reserve in patients with liver disease. Gut 1990, 41, 694-697. [CrossRef]

13. Schechter, P.J.; Giroux, E.L.; Schlienger, J.L.; Hoenig, V.; Sjoerdsma, A. Distribution of serum zinc between albumin and $\alpha^{2}$-macroglobulin in patients with decompensated hepatic cirrhosis. Eur. J. Clin. Investig. 1976, 31, 147-150. [CrossRef]

14. Kiilerich, S.; Christiansen, C. Distribution of serum zinc between albumin and $\alpha^{2}$-macroglobulin in patients with different zinc metabolic disorders. Clin. Chim. Acta 1986, 154, 1-6. [CrossRef]

15. Karayalcin, S.; Arcasoy, A.; Uzunalimoglu, O. Zinc plasma levels after zinc tolerance test in nonalcoholic cirrhosis. Dig. Dis. Sci. 1988, 33, 1096-1102. [CrossRef] [PubMed]

16. McClain, C.J.; Antonow, D.R.; Cohen, D.A.; Shedlofsky, S.I. Zinc metabolism in alcoholic liver disease. Alcohol. Clin. Exp. Res. 1986, 10, 582-589. [CrossRef]

17. Grüngreiff, K.; Franke, D.; Lössner, B.; Abicht, K.; Kleine, F.D. Zinc deficiency-A factor in the pathogenesis of hepatic encephalopathy. Z. Gastroenterol. 1991, 29, 101-106.

18. Rabbani, P.; Prasad, A.S. Plasma ammonia and liver ornithine carbamyltransferase activity in deficient rats. Am. J. Physiol. 1978, 235, E203-E206. [PubMed]

19. Riggio, O.; Merli, M.; Capocaccia, L.; Cashera, M.; Zullo, A.; Pinto, G.; Gaudio, E.; Franchitto, A.; Spagnoli, R.; D'Aquilino, E.; et al. Zinc supplementation reduces blood ammonia and increases liver transcarbamylase activity in experimental cirrhosis. Hepatology 1992, 16, 785-789. [CrossRef] [PubMed] 
20. Yoshida, Y.; Higashi, T.; Nouso, K.; Nakatsukasa, H.; Nakamura, S.I.; Watanabe, A. Effects of zinc deficiency/zinc supplementation on ammonia metabolism in patients with decompensated liver cirrhosis. Acta Med. Okayama 2001, 55, 349-355. [PubMed]

21. Grüngreiff, K.; Presser, H.J.; Franke, D.; Lössner, B.; Kleine, F.D. Correlations between zinc, amino acids and ammonia in liver cirrhosis. Z. Gastroenteriol. 1989, 27, 731-735.

22. El-Serag, H.B. Hepatocellular carcinoma. N. Engl. J. Med. 2011, 365, 1118-1127. [CrossRef] [PubMed]

23. Miatto, O.; Casaril, M.; Gabrielli, B.G.; et al. Diagnostic and prognostic value of serum copper and plasma fibrinogen in hepatic carcinoma. Cancer 1985, 55, 774-778. [CrossRef]

24. Pramoolsinsap, C.; Promvanit, N.; Komindr, S.; Lerdverasirikul, P.; Srianujata, S. Serum trace metals in chronic viral hepatitis and hepatocellular carcinoma in Thailand. J. Gastroenterol. 1994, 29, 610-615. [CrossRef] [PubMed]

25. Grussamy, K. Trace element concentration in primary liver cancers-a systematic review. Biol. Trace Elem. Res. 2007, 118, 191-206. [CrossRef] [PubMed]

26. Himoto, T.; Fujita, K.; Nomura, T.; Tani, J.; Miyoshi, H.; Morishita, A.; Yoneyaka, H.; Kubota, S.; Haba, R.; Suzuki, Y.; Masaki, T. Roles of hepatocarcinogenesis via the activation of hypoxia-inducible factor-1. Biol. Trace Elem. Res. 2016, 174, 58-64. [CrossRef] [PubMed]

27. Ebara, M.; Fukuda, H.; Hatano, R.; Saisho, H.; Nagato, Y.; Suzuki, K.; Nakajima, K.; Yukawa, M.; Kondo, F.; Nakayama, A.; Sakurai, H. Relationship between copper, zinc and metallothionein in hepatocellular carcinoma and its surrounding liver parenchyma. J. Hepatol. 2000, 33, 415-422. [CrossRef]

28. Maeda, T.; Shimada, M.; Harimoto, N.; Tsujita, E.; Maehara, S.; Rikimaru, T.; Tanaka, S.; Shirabe, K.; Maehara, Y. Role of tissue trace elements in liver cancers and non-cancerous liver parenchyma. Hepatogastroenterology 2005, 52, 187-190. [PubMed]

29. Franklin, R.B.; Costello, L.C. The important role of the apoptitic effects of zinc in the development of cancers. J. Cell Biochem. 2009, 106, 750-757. [CrossRef] [PubMed]

30. Nardinocci, L.; Pantisano, V.; Puca, R.; Porru, M.; Aiello, A.; Graselli, A.; Leonetti, C.; Safran, M.; Rechavi, G.; Givol, D.; et al. Zinc downregulates HIF-1 and inhibits its activity in tumor cells in vitro and in vivo. PLoS ONE 2010, 13, e15048.

31. Poo, J.L.; Rosas-Romero, R.; Montemayor, A.C.; Isoard, F.; Uribe, M. Diagnostic value of the copper/zinc ratio in hepatocellular carcinoma: A case control study. J. Gastroenterol. 2003, 38, 45-51. [CrossRef] [PubMed]

32. Lin, C.C.; Huang, J.F.; Tsai, L.Y.; Huang, Y.L. Selenium, iron, copper, and zinc levels and copper-to-zinc ratios in xserum of patients at different stages of viral hepatic diseases. Biol. Trace Elem. Res. 2006, 109, 15-23. [CrossRef]

33. Overbeck, S.; Rink, L.; Haase, H. Modulating the immune response by oral zinc supplemrentation: A single approach for multiple diseases. Arch. Immunol. Ther. Exp. 2008, 56, 15-30. [CrossRef] [PubMed]

34. Zhang, Y.; Chen, C.; Yao, Q.; Li, M. ZIP4 upregulates the expression of neuropilin-1, vascular endothelial growth factor, and matrix metalloproteases in pancreatric cancer cell lines and xenografts. Cancer Biol. Ther. 2010, 9, 234-242. [CrossRef]

35. Hogstrand, C.; Kille, P.; Nicholson, R.I.; Taylor, K.M. Zinc transporters and cancer: A potential role for ZIP7 as a hub for tyrosine kinase activation. Trends Mol. Med. 2009, 15, 101-111. [CrossRef] [PubMed]

36. Kagara, N.; Tanaka, N.; Noguchi, S.; Hirano, T. Zinc and its regulator ZIP10 are involved in invasive behavior of breast cancer cells. Cancer Sci. 2007, 98, 692-697. [CrossRef] [PubMed]

37. Franklin, R.B.; Levy, B.A.; Zou, J.; Hanna, N.; Desouki, M.M.; Bagasra, O.; Johnson, L.A.; Costello, L.C. ZIP14 zinc transporter downregulation and zinc depletion in the development and progression of hepatocellular cancer. J. Gastroenterol. Cancer 2012, 43, 249-257. [CrossRef] [PubMed]

38. Wang, F.D.; Kim, B.E.; Dufner-Beattie, J.; Petris, M.J.; Andrews, G.; Eide, D.J. Acrodermatitis enteropathica mutations affect transport activity, localization and zinc-responsiveness trafficking of the mouse ZIP4 zinc transporter. Hum. Mol. Genet. 2004, 13, 563-571. [CrossRef] [PubMed]

39. Weaver, B.P.; Zhang, Y.; Hiscox, S.; Guo, G.L.; Apte, U.; Taylor, K.M.; Sheline, C.T.; Wang, L.; Andrews, G.K. Zip4 (Slc39a4) expression is activated in hepatocellular carcinomas and functions to repress apoptosis, enhance cell cycle and increase migration. PLoS ONE 2010, 5, e13158. [CrossRef] [PubMed]

40. Xu, X.; Guo, H.J.; Xie, H.Y.; Li, J.; Zhung, R.Z.; Ling, Q.; Zhou, L.; Wei, X.Y.; Liu, Z.K.; Ding, S.M.; et al. ZIP4, a novel determinant of tumor invasion in hepatocellular carcinoma, contributes to tumor recurrence after liver transplantation. Int. J. Biol. Sci. 2014, 10, 235-256. [CrossRef] [PubMed] 
41. Consolo, M.; Amoroso, A.; Spandidos, D.A.; Mazzarino, M.C. Matrix metalloproteinases and their inhibitors as markers of inflammation and fibrosis in chronic liver disease (Review). Int. J. Mol. Med. 2009, 24, 143-152. [PubMed]

42. Imai, K.; Beppu, T.; Yamao, T.; Okabe, H.; Hayashi, H.; Nitta, H.; Hashimoto, D.; Mima, K.; Nakagawa, S.; Sakamoto, K.; et al. Clinicopathological and prognostic significance of preoperative serum zinc status in patients with hepatocellular carcinoma after initial hepatectomy. Ann. Surg. Oncol. 2014, 21, 3817-3826. [CrossRef] [PubMed]

43. Thrift, A.P.; El-Serag, H.B.; Kanwal, F. Global epidemiology and burden of HCV infection and HCV-related disease. Nat. Rev. Gastroenterol. Hepatol. 2017, 14, 122-132. [CrossRef] [PubMed]

44. Okuda, M.; Li, K.; Beard, M.R.; Showalter, L.A.; Scholle, F.; Lemon, S.M.; Weinman, S.A. Mitochondrial injury, oxidative stress, and antioxidant gene expression are induced by hepatitis $\mathrm{C}$ virus core protein. Gastroenterology 2002, 122, 366-375. [CrossRef] [PubMed]

45. Negro, F.; Sanyal, A.J. Hepatitis C virus, steatosis and lipid abnormalities: Clinical and pathologic data. Liver Int. 2009, 29, 26-37. [CrossRef] [PubMed]

46. Kohgo, Y.; Ikuta, K.; Ohtake, T.; Torimoto, Y.; Kato, J. Iron overload and cofactors with special reference to alcohol, hepatitis C virus infection and steatosis/insulin resistance. World J. Gastroenterol. 2007, 13, 4699-4706. [CrossRef] [PubMed]

47. Prasad, A.S.; Boa, B.; Beck, F.W.; Kucuk, O.; Sarkar, F.H. Antioxidant effects of zinc in human. Free Radic. Biol. Med. 2004, 37, 1182-1190. [CrossRef] [PubMed]

48. Ko, W.S.; Guo, C.H.; Yeh, M.S.; Lin, L.Y.; Hsu, G.S.; Chen, P.C.; Luo, M.C.; Lin, C.Y. Blood micronutrient, oxidative stress, and viral load in patients with chronic hepatitis C. World J. Gastroenterol. 2005, 11, 4697-4702. [CrossRef] [PubMed]

49. Moriyama, M.; Matsumura, H.; Fukushima, A.; Ohkido, K.; Arakawa, Y.; Nirei, K.; Aoki, H.; Yamagami, H.; Kaneko, M.; Tanaka, N.; Arakawa, Y. Clinical significance of evaluation of serum zinc concentrations in C-virus chronic liver disease. Dig. Dis. Sci. 2006, 51, 1967-1977. [CrossRef] [PubMed]

50. Stempniak, M.; Hostomska, Z.; Nodes, B.R.; Hostomsky, Z. The NS3 proteinase domain of hepatitis C virus is a zinc-containing enzyme. J. Virol. 1997, 71, 2881-2886. [PubMed]

51. Tellinghuisen, T.L.; Marcotrigiano, J.; Gorbalenya, A.E.; Rice, C.M. The NS5A protein of hepatitis C virus is a zinc metalloprotein. J. Biol. Chem. 2004, 279, 48576-48587. [CrossRef] [PubMed]

52. Chalasani, N.; Younossi, Z.; Lavine, J.E.; Diehl, A.M.; Brunt, E.M.; Cusi, K.; Charlton, M.; Sanyal, A.J. The diagnosis and management of non-alcoholic fatty liver disease: Practice guideline by the American association for the study of liver diseases, American College of Gastroenterology, and the American Gastroenterological Association. Hepatology 2012, 55, 2005-2023. [CrossRef] [PubMed]

53. Zolfaghari, H.; Askari, G.; Siassi, F.; Feizi, A.; Sotoudeh, G. Intake of nutrients, fiber, and sugar in patients with nonalcoholic fatty liver disease in comparison to healthy individuals. Int. J. Prev. Med. 2016, 7, 98. [PubMed]

54. Toshimitsu, K.; Matsuura, B.; Ohkubo, I.; Niiya, T.; Furukawa, S.; Hiasa, Y.; Kawamura, M.; Ebihara, K.; Onji, M. Dietary habits and nutrient intake in non-alcoholic steatohepatitis. Nutrition 2007, 23, 46-52. [CrossRef] [PubMed]

55. Malhi, H.; Kaufman, R.J. Endoplasmic reticulum stress in liver disease. J. Hepatol. 2011, 54, 795-809. [CrossRef] [PubMed]

56. Kim, M.H.; Aydemir, T.B.; Cousins, R.J. Dietary zinc regulates apoptosis through the phosphorylated eukaryotic initiation factor $2 \alpha$ /activating transcription factor-4/C/EBP-homologous protein pathway during pharmacologically induced endoplasmic reticulum stress in livers of mice. J. Nutr. 2016, 146, 2180-2186. [CrossRef] [PubMed]

57. Kim, M.H.; Aydemir, T.B.; Kim, J.; Cousins, R.J. Hepatic ZIP14-mediated zinc transport is required for adaptation to endoplasmic reticulum stress. Proc. Natl. Acad. Sci. USA 2017, 114, E5805-E5814. [CrossRef] [PubMed]

58. Sakurai, H.; Adachi, Y. The pharmacology of the insulinomimetic effect of zinc complexes. Biometals 2005, 18, 319-323. [CrossRef] [PubMed]

59. Walter, R.M., Jr.; Uriu-Hare, J.Y.; Olin, K.L.; Oster, M.H.; Anawalt, B.D.; Critchfield, J.W.; Keen, K.L. Copper, zinc, manganese, and magnesium status and complications of diabetes mellitus. Diabetes Care 1991, 14, 1050-1056. [CrossRef] [PubMed] 
60. Allison, M.E.; Wreghitt, T.; Palmer, C.R.; Alexander, G.J. Evidence for a link between hepatitis C virus infection and diabetes mellitus in a cirrhotic population. J. Hepatol. 1994, 21, 1135-1139. [CrossRef]

61. Himoto, T.; Yoneyama, H.; Deguchi, A.; Kurokohchi, K.; Inukai, M.; Masugata, H.; Goda, F.; Senda, S.; Haba, R.; Watanabe, S.; Kubota, S.; Kuriyama, S.; Masaki, T. Insulin resistance derived from zinc deficiency in non-diabetic patients with chronic hepatitis C. Exp. Ther. Med. 2010, 1, 707-711. [CrossRef] [PubMed]

62. Himoto, T.; Nomura, T.; Tani, J.; Miyoshi, H.; Morishita, A.; Yoneyama, H.; Haba, R.; Masugata, H.; Masaki, T. Exacerbation of insulin resistance and hepatic steatosis deriving from zinc deficiency in patients with HCV-related chronic liver disease. Biol. Trace. Elem. Res. 2015, 163, 81-88. [CrossRef] [PubMed]

63. Rajaram, S.; Baylink, D.J.; Mohan, S. Insulin-like growth factor-binding proteins in serum and other biological fluids: Regulation and functions. Endocr. Rev. 1997, 18, 801-831. [CrossRef] [PubMed]

64. Himoto, T.; Tani, J.; Miyoshi, H.; Yoneyama, H.; Mori, H.; Inukai, M.; Masugata, H.; Goda, F.; Senda, S.; Haba, R.; Masaki, T. The ratio of insulin-like growth factor-I/insulin-like growth factor-binding protein-3 in sera of patients with chronic hepatitis $C$ virus-related chronic liver disease as a predictive marker of insulin resistance. Nutr. Res. 2013, 33, 27-33. [CrossRef] [PubMed]

65. Ichikawa, T.; Nakao, K.; Hamasaki, K.; Furukawa, R.; Tsuruta, S.; Ueda, Y.; Taura, N.; Shibata, H.; fujimoto, M.; Toriyama, K.; Eguchi, K. Role of growth hormone, insulin-like growth factor 1 and insulin-like growth factor-binding protein 3 in development of non-alcoholic fatty liver disease. Hepatol. Int. 2007, 1, $287-294$. [CrossRef] [PubMed]

66. European Association for the Study of the Liver. EASL clinical practice guideline: The diagnosis and management of patients with primary biliary cholangitis. J. Hepatol. 2017, 67, 145-172.

67. Himoto, T.; Yoneyama, H.; Kurokochi, K.; Inukai, M.; Masugata, H.; Goda, F.; Haba, R.; Watanabe, S.; Senda, S.; Masaki, T. Contribution of zinc deficiency to insulin resistance in patients with primary biliary cirrhosis. Biol. Trace Elem. Res. 2011, 144, 133-142. [CrossRef] [PubMed]

68. Formigari, A.; Santon, A.; Irato, P. Efficacy of zinc treatment against iron-induced toxicity in rat hepatoma cell line H4-II-E-C3. Liver Int. 2007, 27, 120-127. [CrossRef] [PubMed]

69. Liuzzi, J.P.; Aydemir, F.; Nam, H. Zip14 (Slc39a14) mediates non-transferrin-bound iron uptake into cells. Proc. Natl. Acad. Sci. USA 2006, 103, 13612-13617. [CrossRef] [PubMed]

70. Fernandez-Real, J.M.; Lopes-Bermejo, A.; Ricart, W. Cross-talk between iron metabolism and diabetes. Diabetes 2002, 51, 2348-2354. [CrossRef] [PubMed]

71. Mendler, M.H.; Turlin, B.; Moirand, R. Insulin resistance-associated hepatic iron overload. Gastroenterology 1999, 117, 1155-1163. [CrossRef]

72. Farinati, F.; Cardin, R.; De Maria, N.; Lecis, P.E.; Della Libera, G.; Burra, P.; Marafin, C.; Stumiolo, G.C.; Naccarato, R. Iron storage, lipid peroxidation and glutathione turn over in chronic anti-HCV positive hepatitis. J. Hepatol. 1995, 22, 449-456. [CrossRef]

73. Conover, C.A. Potentiation of insulin-like growth factor (IGF) action by IGF-binding protein-3: Studies of underlying mechanism. Endocrinology 1992, 130, 3191-3199. [CrossRef] [PubMed]

74. McNall, A.D.; Etherton, T.D.; Fosmire, G.J. The impaired growth induced by zinc deficiency in rat is associated with decreased expression of the hepatic insulin-like growth factor I and growth hormone receptor genes. J. Nutr. 1995, 125, 874-879. [PubMed]

75. Mikhail, T.H.; Nicola, W.G.; Ibrahim, K.H.; Salama, S.H.; Eman, M. Abnormal zinc and copper metabolism in hepatic steatosis. Boll. Chim. Farm. 1996, 135, 591-597. [PubMed]

76. Bao, B.; Prasad, A.S.; Beck, F.W.; Fitzgerald, J.T.; Snell, D.; Bao, G.W.; Singh, T.; Cardozo, L.J. Zinc decreases C-reactive protein, lipid peroxidation, and inflammatory cytokines in elderly subjects: A potential implication of zinc as an atheroprotective agent. Am. J. Clin. Nutr. 2010, 91, 1634-1641. [CrossRef] [PubMed]

77. Runchery, S.S.; Boyko, E.J.; Ioannou, G.N.; Ultzschneider, K.M. The relationship between serum circulating IGF-1 and liver fat in the United States. J. Gasroenterol. Hepatol. 2014, 29, 589-596. [CrossRef]

78. Lalioti, V.; Sandoval, I.; Cassio, D.; Duclos-Vallee, J.C. Molecular pathology of Wilson's disease: A brief. J. Hepatol. 2010, 53, 1151-1153. [CrossRef] [PubMed]

79. Ferenci, P. Wioson's disease. Ital. J. Gastroenterol. Hepatol. 1999, 31, 416-425. [PubMed]

80. Pietrangelo, A. Hereditary hemochromatosis: Pathogenesis, diagnosis, and treatment. Gastroenterology 2010, 139, 393-408. [CrossRef] [PubMed] 
81. Vayenas, D.V.; Repanti, M.; Vassilopoulos, A.; Papanastasiou, D.A. Influence of iron overload on manganese, zinc, and copper concentration in rat tissues in vivo: Study of liver, spleen, and brain. Int. J. Clin. Lab. Res. 1998, 28, 183-186. [CrossRef] [PubMed]

82. Adams, P.C.; Bradley, C.; Frei, J.V. Hepatic zinc in hemochromatosis. Clin. Invest. Med. 1991, 14, 16-20. [PubMed]

83. Beckett, J.M.; Ball, M.J. Effect of hereditary haemochromatosis genotypes and iron overload on other trace elements. Eur. J. Nutr. 2013, 52, 255-261. [CrossRef] [PubMed]

84. Himoto, T.; Hosomi, N.; Nakai, S.; Deguchi, A.; KInekawa, F.; Matsuki, M.; Yachida, M.; Masaki, T.; Kurokochi, K.; Watanabe, S.; et al. Efficacy of zinc administration in patients with hepatitis C virus-related chronic liver disease. Scand. J. Gastroenterol. 2007, 42, 1078-1087.

85. Takagi, H.; Nagamine, T.; Abe, T.; Takayama, H.; Sato, K.; Otsuka, T.; Kakizaki, S.; Hashimoto, Y.; Matsumoto, T.; Kojima, A.; et al. Zinc supplementation enhances the response to interferon therapy in patients with chronic hepatitis C. J. Viral. Hepat. 2001, 8, 367-371. [CrossRef] [PubMed]

86. Murakami, Y.; Koyabu, T.; Kawashima, A.; Kakibuchi, N.; Kawakami, T.; Takaguchi, K.; Kita, K.; Okita, M. Zinc supplementation prevents the increase of transaminase in chronic hepatitis $\mathrm{C}$ patients during combination therapy with pegylated interferon $\alpha-2 b$ and ribavirin. J. Nutr. Sci. Vitaminol. 2007, 53, 213-218. [CrossRef] [PubMed]

87. Yoshikawa, Y.; Adachi, Y.; Sakurai, H. A new type of orally active anti-diabetic Zn (II)-dithiocarbamate complex. Life. Sci. 2007, 80, 759-766. [CrossRef] [PubMed]

88. Jayawardena, R.; Ranasinghe, P.; Galappatthy, P.; Malkanthi, R.; Constantine, G.; Katulanda, P. Effects of zinc supplementation on diabetes mellitus: a systematic review and meta-analysis. Diabetol. Metab. Syndr. 2012, 4, 13. [CrossRef] [PubMed]

89. Marchesini, G.; Bugianesi, E.; Ronchi, M.; Flamia, R.; Thomaseth, K.; Pacini, G. Zinc supplementation improves glucose disposal in patients with cirrhosis. Metabolism 1998, 47, 792-798. [CrossRef]

90. Sugino, H.; Kumagai, N.; Watanabe, S.; Toda, K.; Takeuchi, O.; Tsunematsu, S.; Morinaga, S.; Tsuchimoto, K. Polaprezinc attenuates liver fibrosis in a mouse model of non-alcoholic steatohepatitis. J. Gastroenterol. Hepatol. 2008, 23, 1909-1916. [CrossRef] [PubMed]

91. Kang, X.; Zhong, W.; Liu, J.; Song, Z.; McClain, C.J.; Kang, Y.J.; Zhou, Z. Zinc supplementation reverses alcohol-induced steatosis in mice through reactivating hepatocyte nuclear factor- $4 \alpha$ and peroxisome proliferator-activated receptor- $\alpha$. Hepatology 2009, 50, 1241-1250. [CrossRef] [PubMed]

92. Cave, M.; Deaciuc, I.; Mendez, C.; Sing, Z.; Joshi-Barve, S.; Barve, S.; McClain, C. Nonalcoholic fatty liver disease: Predisposing factors and the role of nutrition. J. Nutr. Biochem. 2007, 18, 184-195. [CrossRef] [PubMed]

93. Reding, P.; Duchateau, J.; Bataille, C. Oral zinc supplementation improves hepatic encephalopathy. Results of randomized controlled trial. Lancet 1984, 2, 493-495. [CrossRef]

94. Marchesini, G.; Fabri, A.; Bianchi, G.; Brizi, M.; Zoil, M. Zinc supplementation and amino acid-nitrogen metabolism in patients with advanced cirrhosis. Hepatology 1996, 23, 1084-1092. [CrossRef] [PubMed]

95. Grüngreiff, K.; Grüngreiff, S.; Reinhold, D. Zinc deficiency and hepatic encephalopathy: Results of a long-term follow-up on zinc supplementation. J. Trace. Elem. Exp. Med. 2000, 13, 21-31. [CrossRef]

96. Takuma, Y.; Nouso, K.; Makino, Y.; Hayashi, M.; Takahashi, H. Clinical trial: Oral zinc in hepatic encephalopathy. Aliment. Pharmacol. Ther. 2010, 32, 1080-1090. [CrossRef] [PubMed]

97. Katayama, K.; Saito, M.; Kawaguchi, T.; Endo, R.; Sawara, K.; Nishiguchi, S.; Kato, A.; Kohgo, H.; Suzuki, K.; Sakaida, I.; et al. Effect of zinc on liver cirrhosis with hyperammonia: A preliminary randomized, placebo-controlled double-blinded trial. Nutrition 2014, 30, 1409-1414. [CrossRef] [PubMed]

98. Kawaguchi, T.; Taniguchi, E.; Sata, M. Effects of oral branched-chain amino acids on hepatic encephalopathy and outcome in patients with liver cirrhosis. Nutr. Clin. Pract. 2013, 28, 580-588. [CrossRef] [PubMed]

99. Hayashi, M.; Ohnishi, H.; Kawade, Y.; Muto, Y.; Takahashi, Y. Augmented utilization of branched-chain amino acids by skeletal muscle in decompensated liver cirrhosis in special relation to ammonia detoxication. Gastroenterol. Jpn. 1981, 16, 64-70.

100. Matsumura, H.; Nirei, K.; Nakamura, H.; Arakawa, Y.; Higuchi, T.; Hayashi, J.; Yamagami, H.; Matsuoka, S.; Ogawa, M.; Nakajima, N.; et al. Zinc supplementation therapy improves the outcome of patients with chronic hepatitis C. J. Clin. Biochem. Nutr. 2012, 51, 178-184. [PubMed] 
101. El-Serag, H.B.; Tran, T.; Everhart, J.E. Diabetes increases the risk of chronic liver disease and hepatocellular carcinoma. Gastroenterology 2004, 126, 460-468. [CrossRef] [PubMed]

102. Kawaguchi, T.; Sata, M. Importance of hepatitis $C$ virus-associated insulin resistance: Therapeutic strategies for insulin sensitization. World J. Gastroenterol. 2010, 16, 1943-1952. [CrossRef] [PubMed]

103. Mulder, T.P.; Janssens, A.R.; Verspaget, H.W.; van Hattum, J.; Lamers, C.B. Metallothionein concentration in the liver of patients with Wilson's disease, primary biliary cirrhosis, and liver metastasis of colorectal cancer. J. Hepatol. 1992, 16, 346-350. [CrossRef]

104. Brewer, G.J.; Yuzbasiyan-Gurkan, V.; Lee, D.Y.; Appelman, H. Treatment of Wilson's disease with zinc. VI. Initial treatment studies. J. Lab. Clin. Med. 1989, 114, 633-638. [PubMed]

105. Sturniolo, G.C.; Mestriner, C.; Irato, P.; Albergoni, V.; Longo, G.; D'Inca, R. Zinc therapy increases duodenal concentrations of metallothionein and iron in Wilson's disease patients. Am. J. Gastroenterol. 1999, 94, 334-338. [CrossRef] [PubMed]

106. Shimizu, N.; Fujuwara, J.; Ohnishi, S.; Sato, M.; Kodama, H.; Kohsaka, T.; Inui, A.; Fujisawa, T.; Tamai, H.; Ida, S.; et al. Effects of long-term zinc treatment in Japanese patients with Wilson disease: Efficacy, stability, and copper metabolism. Trans. Res. 2010, 156, 350-357. [CrossRef] [PubMed]

107. Duncan, A.; Yacoubian, C.; Watson, N.; Morrison, I. The risk copper deficiency in patients prescribed zinc supplementation. J. Clin. Pathol. 2015, 68, 723-725. [CrossRef] [PubMed]

108. Gammoh, N.Z.; Rink, L. Zinc in infection and inflammation. Nutrients 2017, 9, 624. [CrossRef] [PubMed]

109. Hartman, H.J. Copper-thionein from fetal bovine liver. Biochim. Biophys. Acta. 1977, 491, 211-222.

110. Milne, D.B.; Davis, C.D.; Nielsen, F.H. Low dietary zinc alters indices of copper function and status in postmenopausal women. Nutrition 2001, 17, 701-708. [CrossRef]

111. Garafalo, J.A.; Ashiraki, H.; Menendez-Botet, C.; Cunningham-Rundles, S.; Schwartz, M.K.; Good, R.A. Serum zinc, copper, and the copper/zinc ratio in patients with benign and malignant breast lesions. Cancer 1980, 46, 2682-2685. [CrossRef]

112. Stepien, M.; Hughes, D.J.; Hybsier, S.; Bamia, C.; Tjønneland, A.; Overvad, K.; Affret, A.; His, M.; Boutron-Ruault, M.C.; Katzke, V.; et al. Circulating copper and zinc levels and risk of hepatobiliary cancers in Europeans. Br. J. Cancer 2017, 116, 688-696. [CrossRef] [PubMed]

113. Guo, C.H.; Chen, P.C.; Ko, W.S. Status of essential trace minerals and oxidative stress in viral hepatitis C patients with nonalcoholic fatty liver disease. Int. J. Med.Sci. 2013, 10, 730-737. [CrossRef] [PubMed]

114. Himoto, T.; Yoneyama, H.; Kurokohchi, K.; Inukai, M.; Masugata, H.; Goda, F.; Haba, R.; Watanabe, S.; Kubota, S.; Senda, T.; et al. Selenium deficiency is associated with insulin resistance in patients with hepatitis C virus-related chronic liver disease. Nutr. Res. 2011, 31, 829-835. [CrossRef] [PubMed]

115. Thuluvath, P.J.; Triger, D.R. Selenium in chronic liver disease. J. Hepatol. 1992, 14, 176-182. [CrossRef]

116. Fatmi, W.; Kechrid, Z.; Naziroglu, M.; Flores-Arce, M. Selenium supplementation modulates zinc levels and antioxidant values in blood and tissues of diabetic rats fed zinc-deficient diet. Biol. Trace. Elem. Res. 2013, 152, 243-250. [CrossRef] [PubMed]

117. Schölmerich, J.; Becher, M.S.; Köttgen, E.; Rauch, N.; Haussinger, D.; Löhle, E.; Vulleumier, J.P.; Gerok, W. The influence of portosystemic shunting on zinc and vitamin A metabolism in liver cirrhosis. Hepatogastroenterology 1983, 30, 143-147. [PubMed]

118. Smith, J.C., Jr. The vitamin A-zinc connection: A review. Ann. N.Y. Acad. Sci. 1980, 355, 62-75. [CrossRef]

119. Solomons, N.W.; Russell, R.M. The interaction of vitamin A and zinc: Implications for human nutrition. Am. J. Clin. Nutr. 1980, 33, 2031-2040. [PubMed]

120. Petta, S.; Camma, C.; Scazzone, C.; Tripodo, C.; Di Marco, V.; Bono, A.; Cabibi, D.; Licata, G.; Porcasi, R.; Marchesini, G. Low vitamin D serum level is related to severe fibrosis and low responsiveness to interferon-based therapy in genotype 1 chronic hepatitis C. Hepatology 2010, 51, 1158-1167. [CrossRef] [PubMed]

121. Reda, R.; Abbas, A.A.; Mohammed, M.; El Fedawy, S.F.; Ghareeb, H.; El Kabarity, R.H.; Abo-Shady, R.A.; Zakaria, D. The interplay between zinc, vitamin D and, IL-17 in patients with chronic hepatitis C liver disease. J Immunol. Res. 2015, 2015, 846348. [CrossRef] [PubMed]

122. Kebapcilar, A.G.; Kulaksizoglu, M.; Kebapcilar, L.; Gonen, M.S.; Unlü, A.; Topcu, A.; Demirci, F.; Taner, C.E. Is there a link between premature ovarian failure and serum concentration of vitamin $\mathrm{D}$, zinc, and copper? Menopause 2013, 20, 94-99. [CrossRef] [PubMed] 
123. Fukushima, H.; Miwa, Y.; Shiraki, M.; Gomi, I.; Toda, K.; Kuriyama, S.; Nakamura, H.; Wakahara, H.; Era, S.; Moriwaki, H. Oral branched-chain amino acid supplementation improves the oxidized/reduced albumin ratio in patients with liver cirrhosis. Hepatol. Res. 2007, 37, 765-770. [CrossRef] [PubMed]

124. Faure, H.; Leverve, X.; Amaud, J.; Boujet, C.; Favier, A. Zinc changes in blood and urine during cyclic parenteral nutrition: Relationships with amino acid metabolism. Br. J. Nutr. 1994, 72, 763-773. [CrossRef] [PubMed]

125. Prasad, A.S. Impact of the discovery of human zinc deficiency on health. J. Am. Coll. Nutr. 2009, 28, 257-265. [CrossRef] [PubMed]

126. Fuse, H.; Kazama, T.; Ohta, S.; Fujiuchi, Y. Relationship between zinc concentrations in seminal plasma and various sperm parameters. Int. Urol. Nephrol. 1999, 31, 401-408. [CrossRef] [PubMed]

(c) 2018 by the authors. Licensee MDPI, Basel, Switzerland. This article is an open access article distributed under the terms and conditions of the Creative Commons Attribution (CC BY) license (http:// creativecommons.org/licenses/by/4.0/). 